\title{
Preparation and Characterization of Silica Nanoparticles by Wet Mechanical Attrition of White and Yellow Sand
}

\author{
Magda A AkI ${ }^{1 *}$, Hesham F Aly², Hesham M A Soliman ${ }^{3}$, Aref M. E. Abd EIRahman ${ }^{3}$ and Ahmed I. Abd-Elhamid ${ }^{3}$ \\ ${ }^{1}$ Chemistry Department, Faculty of Science, Mansoura University, Mansoura, Egypt \\ ${ }^{2}$ Hot Laboratories Center, Atomic Energy Authority, 13759, Egypt \\ ${ }^{3}$ Advanced Technology and New Materials Research Institute, City for Scientific Research and Technology Applications, Borg El arab, P. O. Box 21934, Alexandria, Egypt
}

\begin{abstract}
Mechanical alloying is a simple and useful processing technique that is now being employed in the production of nanocrystals and/or nanoparticles from all material classes. In the present work, preparation of silica nanoparticles $\left(\mathrm{SiO}_{2} \mathrm{NPs}\right)$ by wet mechanical attrition of white and yellow sand using a lab scaled ball mill was investigated. The different experimental parameters affecting the milling process were thoroughly studied such as the milling period, water volume and the initial size of sand particles. Analysis of the results obtained revealed that $\mathrm{SiO}_{2} \mathrm{NPs}$ with particle size $22-33 \mathrm{~nm}$ and $38-48 \mathrm{~nm}$ could successfully be prepared from original white and yellow sand, respectively. The optimum experimental parameters to obtain these $\mathrm{SiO}_{2} \mathrm{NPs}$ are $25 \mathrm{~g}$ original sand particle, $50 \mathrm{ml}$ water, $113 \mathrm{~g}$ media weight and $8 \mathrm{hr}$ milling period at $400 \mathrm{rpm}$ mill speed. The $\mathrm{SiO}_{2} \mathrm{NPs}$ obtained were characterized by SEM, XRD, EDS and FTIR. The results obtained showed high homogeneity of the produced spherical $\mathrm{SiO}_{2} \mathrm{NPs}$. These $\mathrm{SiO}_{2} \mathrm{NPs}$ have good potentials for use in industry such as their use as additive materials in ultrahigh performance concrete for the next development. Based on economic value, the produced $\mathrm{SiO}_{2} \mathrm{NPs}$ have excellent potential to be developed.
\end{abstract}

\section{Keywords: Nanosilica, attrition, SEM, XDR, EDS, FTIR}

\section{Introduction}

Nanoparticles from mechanical attrition are produced by a "top-down" process, unlike nanoparticles produced from "bottomup" processes such as self-assembly and template synthesis. These nanoparticles are formed in a mechanical device, generically referred to as a "mill," in which energy is imparted to a course-grained material to effect a reduction in particle size. The resulting particulate powders can exhibit nanostructural characteristics on at least two levels. First, the particles themselves, which normally possess a distribution of sizes, can be "nanoparticles" if their average characteristic dimension (diameter for spherical particles) is less than $100 \mathrm{~nm}$ [1]. Second, many of the materials milled in mechanical attrition devices are highly crystalline, such that the crystallite (grain) size after milling is often between 1 and $10 \mathrm{~nm}$ in diameter. Such materials are termed "nanocrystalline" [2]. The sizes of the nanocrystals and the nanoparticles may or may not be the same. In some of the nanostructured materials literature, particularly that involving bottom-up processes, the term "nanocrystal" is reserved for crystalline particles with low concentrations of defects, such as are found in single crystals, whereas "nanoparticles" are those nanoscale particles that contain gross internal grain boundaries, fractures, or internal disorder, whether the crystals they contain are nanocrystalline or not [3].

The importance of nanoparticles lies in their inherently large surface-to-volume ratio relative to that of larger particles. These high surface areas can potentially improve catalytic processes and interfacially driven phenomena such as wetting and adhesion. Nanoparticles have the potential for use in structural and device applications in which enhanced mechanical and physical characteristics are required. As for the internal structure of the nanoparticles, it has been found that nanocrystalline materials have comparative advantages over their microcrystalline

counterparts in hardness, fracture toughness, and low temperature ductility $[4,5]$. As new methods for surface modification and post attrition processing of nanoparticles are developed, the potential applications for them continue to grow.
$\mathrm{SiO}_{2} \mathrm{NPs}$ are used in many industries such as semiconductor technology, optical communication, removal of heavy metals and dyes from water, catalysts, pigments and pharmacy industry.

$\mathrm{SiO}_{2} \mathrm{NPs}$ have been prepared by several techniques sol -gel process [6-12], microemulsion [13-16], oxidation of tetraethyl-orthosilicate TEOS in the bench-scale diffusion flame reactor [17], an interdigital micromixer and a batch reactor, have been used to prepare silica nanoparticles [18]. Recently, encapsulation of water insoluble drugs in mesoporous silica nanoparticles using supercritical carbon dioxide has been described [19].

A literature survey revealed that little information is available regarding the preparation of $\mathrm{SiO}_{2} \mathrm{NPs}$ by wet mechanical attrition of white and yellow sand. The aim of the present study is to throw light on the preparation and characterization $\mathrm{SiO}_{2} \mathrm{NPs}$ by wet mechanical attrition white and yellow sand based on their following peculiar properties: 1) they have mechanic strength to enhance the usable life. 2) The $\mathrm{SiO}_{2} \mathrm{NPs}$ possess nano-scaled size larger specific surface area allowing the easy adsorption of different environmental pollutants 3 ) the raw materials are low-cost and the synthetic approach is simple, which make these nanoparticles potentially commercializable.

In the present work $\mathrm{SiO}_{2} \mathrm{NPs}$ are obtained by wet mechanical attrition of white and yellow sand. The prepared $\mathrm{SiO}_{2} \mathrm{NPs}$ were characterized by SEM, XRD, EDS and FTIR. The different experimental

*Corresponding author: Magda A Akl, Chemistry Department, Faculty of Science, Mansoura University, Mansoura, Egypt, Tel: 20-5022-42388 ; E-mail: magdaakl@yahoo.com

Received July 08, 2013; Accepted November 28, 2013; Published November 30, 2013

Citation: AkI MA, Aly HF, Soliman HMA, Aref ME, EIRahman A, et al. (2013) Preparation and Characterization of Silica Nanoparticles by Wet Mechanical Attrition of White and Yellow Sand. J Nanomed Nanotechnol 4: 183. doi:10.4172/21577439.1000183

Copyright: (c) 2013 Akl MA, et al. This is an open-access article distributed under the terms of the Creative Commons Attribution License, which permits unrestricted use, distribution, and reproduction in any medium, provided the original author and source are credited. 
factors affecting the milling process were thoroughly investigated. The proposed method is particularly suitable for large quantity production, relatively simple with a few operation parameters, high homogenous product and low cost.

\section{Materials}

All chemicals were of analytical grade and used as received. All required solutions were prepared using de-ionized water, provided from a Milli-Q (Millipore, Bedford, MA, USA) purification system. White sand $\left(\mathrm{S}_{\mathrm{Sil}}\right)$ was obtained from Suez Company for Minerals, Egypt. Yellow sand $\left(\mathrm{S}_{\mathrm{Si} 2}\right)$ was obtained from Borg Al-Arab desert. The two samples used without any further purification Analytical balance of type "Sartorius-GP 3202" was used to weight sand. A Vibratory Sieve Shaker of type "Retsch -AS200" basic was used for sieving of white sand. Milling of sieved white and yellow sand was performed using a "Retsch-PM400" planetary ball mill.

\section{Preparations}

\section{Sieving of sand}

$100 \mathrm{gm}$ of white or yellow sand was placed on a vibratory sieve shaker for $10 \mathrm{~min}$ at an amplitude of $100 \mathrm{~mm}$. The sieving weight for each size fraction is given in Table 1.

\section{Milling of white and yellow sand}

$25 \mathrm{gm}$ of white or yellow sand was placed in a laboratory scaled ball mill. Samples were taken from a well mixed batch. Steel balls were used as milling media, steel veal was used as reactor and the ball mill was adjusted at $400 \mathrm{rpm}$ on a "continuous mode". After every run, a certain amount of milled particles was suspended in an enough amount of double distilled water. A drop of the suspended particles was placed on a glass slide to dry on air to be characterized.

\section{Characterization}

Scanning Electron Microscopy (SEM): The surface morphologies of nanoparticles were investigated using scanning electron microscopy using Scanning Electron Microscopy (SEM) "Jeol Japan -JSM-636 OLA"

X-ray Diffraction Analysis (XRD): The crystallinity of particles was determined by X-ray diffraction (XRD) "Shimadzu, Japan XRD7000"

Energy dispersive spectroscopy (EDS): The elemental analysis was achieved using SEM with EDS unit.

Fourier Transform Infrared Spectroscopy (FTIR): Various vibration modes were performed by Fourier transmission infra red spectroscopy (FTIR)" Shimadzu, Japan-8400s".

\section{Results and Discussion}

\section{Milling of white sand}

Effect of milling period: The influence of milling period on the

\begin{tabular}{|c|c|}
\hline Size $(\boldsymbol{\mu m})$ & Weight $(\mathbf{g m})$ \\
\hline $2000-500$ & 4.5 \\
\hline $500-250$ & 46.5 \\
\hline $250-125$ & 47.65 \\
\hline $125-63$ & 1.05 \\
\hline $63-45$ & 0.15 \\
\hline
\end{tabular}

Table 1: The weight ( $\mathrm{gm})$ for each size $(\mu \mathrm{m})$ of white sand after Sieving $\left(\mathrm{SiO}_{2}\right.$ weight $=100 \mathrm{gm}$ Amplitude $=100 \mathrm{~mm}$ time $\left.=10 \mathrm{~min}\right)$. particle size of $25 \mathrm{~g}(150-250 \mu \mathrm{m})$ of $\mathrm{S}_{\mathrm{Si1}}$ in $50 \mathrm{ml}$ water using $113 \mathrm{~g}$ media weight and mill speed of $400 \mathrm{rpm}$ was investigated. After $6 \mathrm{hr}$ milling, the particle size of the dispersed silica particles was measured by SEM. At low magnification, $2500 \mathrm{X}$, large particles were observed in the range 0.57 to $2.37 \mu \mathrm{m}$, Figure $1 \mathrm{~A}(\mathrm{a} \& \mathrm{~b})$. At higher magnification, $50000 \mathrm{X}, \mathrm{SiO}_{2} \mathrm{NPs}$ were observed in the range $23-38 \mathrm{~nm}$. Under similar conditions and increasing the milling period to 8,16 and $40 \mathrm{hr}$ low magnification, large particles were not observed. At SEM with higher magnification, Figue $1 \mathrm{~B}, \mathrm{C}$ and $\mathrm{D}$, the particle size in the range, 23-38 $\mathrm{nm}$, at $8 \mathrm{hr}, 32-58 \mathrm{~nm}$, at $16 \mathrm{hr}$ and $16-48 \mathrm{~nm}$ at $40 \mathrm{hr}$. The increase in the particle size at $16 \mathrm{hr}$ is due to reverse milling [20]. Eight hours milling period was used for the subsequent milling processes. The relation between the milling period and the obtained $\mathrm{SiO}_{2} \mathrm{NPs}$ is represented in Figure 2.

Effect of water volume: Water was used as a wetting medium. The dependence of $\mathrm{SiO}_{2} \mathrm{NPs}$ on the water volume at milling period: $8 \mathrm{hr}$, sand weight: $25 \mathrm{gm}$, media weight: $113 \mathrm{~g}$ and mill speed: $400 \mathrm{rpm}$ was investigated. Figure 3 shows the low magnification $2500 \mathrm{X}$ SEM of the particles obtained which indicates that with increase the volume of water from 0 to $25 \mathrm{ml}$ the large particles break down into smaller particles with range particles size of 0.51-3.48 $\mu \mathrm{m}, 0.22-2.95 \mu \mathrm{m}$ upon using $0 \mathrm{ml}$ and 25, respectively. Further increase of the volume of water to $50 \mathrm{ml}$ the large particles disappear. At higher magnification, $50000 \mathrm{X}$ $\mathrm{SEM}$, the $\mathrm{SiO}_{2} \mathrm{NPs}$ were seen with average particles size of $22-51 \mathrm{~nm}$, 22-47 $\mathrm{nm}$ and $23-38 \mathrm{~nm}$ upon using 0,25 and $50 \mathrm{ml}$ water, respectively. By addition of water the flow ability of the suspension was improved and there was, no longer, adherent particles to the wall of the vial nor the surface of the balls.

Effect of initial particle size of sand : The effect of initial sand particle size on the size of resulting $\mathrm{SiO}_{2} \mathrm{NPs}$ was investigated. Three samples, each $25 \mathrm{~g}$, were subjected to milling: original sand sample, sample with size $125-250 \mu \mathrm{m}$ and the third sample was in the range $250-500 \mu \mathrm{m} .25 \mathrm{~g}$ of each of the three samples was milled for $8 \mathrm{hr}$ in $50 \mathrm{ml}$ water using $113 \mathrm{~g}$ media weight and $400 \mathrm{rpm}$ mill speed. The particle size obtained from each sample was compared with the particle size obtained from the original sample. It was observed that $\mathrm{SiO}_{2} \mathrm{NPs}$ of particle size, $22-30 \mathrm{~nm}, 25-38 \mathrm{~nm}$ and $23-38 \mathrm{~nm}$ can be obtained upon using sand of initial particle size between $500-250 \mu \mathrm{m}, 250$ $-125 \mu \mathrm{m}$ and the original sand sample, respectively, Fig. 4. It can be concluded that the initial particle size has no effect on the size of the produced $\mathrm{SiO}_{2} \mathrm{NPs}$. The relation between initial particle size and $\mathrm{SiO}_{2}$ NPs is represented in Figure 5. $25 \mathrm{~g}$ of sand was used in all subsequent experiments.

\section{Milling of yellow sand}

The optimum conditions of the previous experimental factors (milling period: $8 \mathrm{hr}$, sand weight: $25 \mathrm{~g}$, media weight: $113 \mathrm{~g}$, water volume: $50 \mathrm{ml}$ and mill speed: $400 \mathrm{rpm}$ ) were applied to yellow sand $\left(\mathrm{S}_{\mathrm{Si2}}\right)$. The SEM images obtained, Figure 6 shows that $\mathrm{SiO}_{2} \mathrm{NPs}$ with size that ranged between $30-47 \mathrm{~nm}$ can be obtained by milling of yellow sand.

\section{Characterization of $\mathrm{SiO}_{2} \mathrm{NPs}$}

XRD: Figures 7 and 8 show the XRD pattern of $\mathrm{SiO}_{2} \mathrm{NPs}$ of the milled white and yellow sand, respectively. Typical silica characteristic is observed with an intense sharp peak centered at $2 \theta=26^{\circ}$ which indicates that the samples are crystalline with crystal size $26.776 \mathrm{~nm}$ and $25.455 \mathrm{~nm}$ for the milled white and yellow sand respectively

EDS: The EDS of white and yellow sand before milling is represented 
Citation: AkI MA, Aly HF, Soliman HMA, Aref ME, EIRahman A, et al. (2013) Preparation and Characterization of Silica Nanoparticles by Wet Mechanical Attrition of White and Yellow Sand. J Nanomed Nanotechnol 4: 183. doi:10.4172/2157-7439.1000183

1.A) $6 \mathrm{hr}$

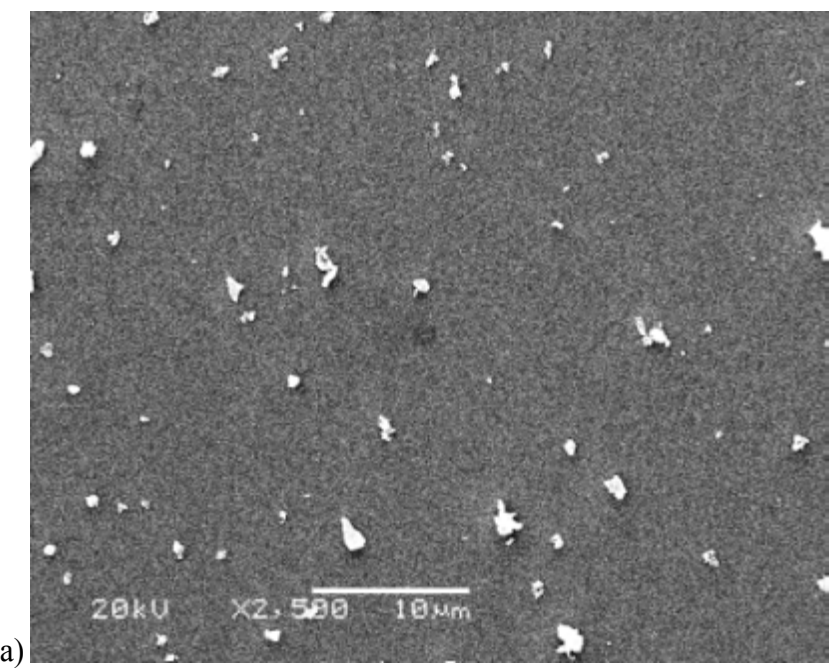

(c)

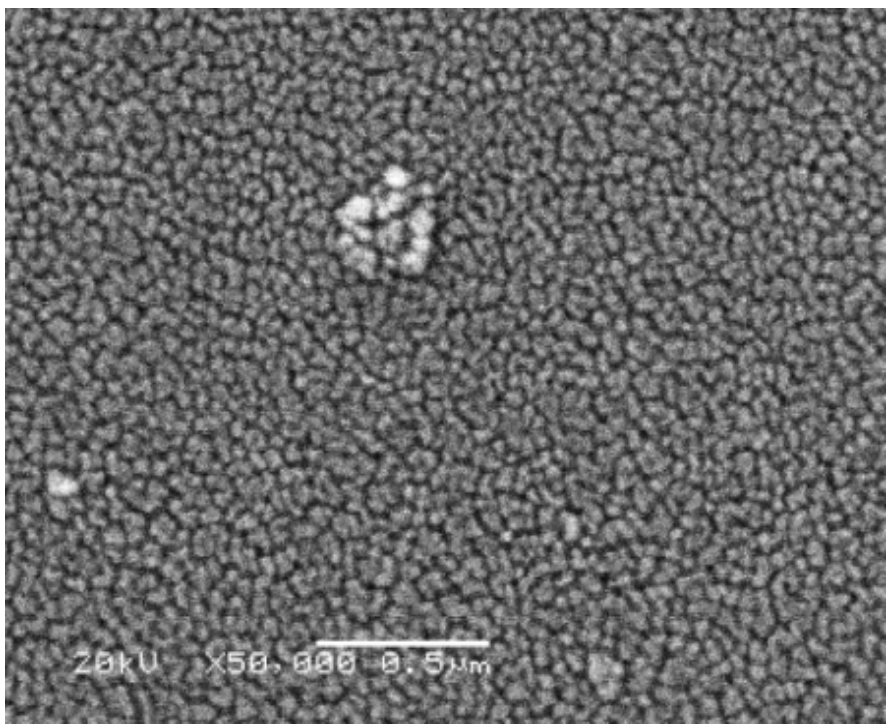

(b)

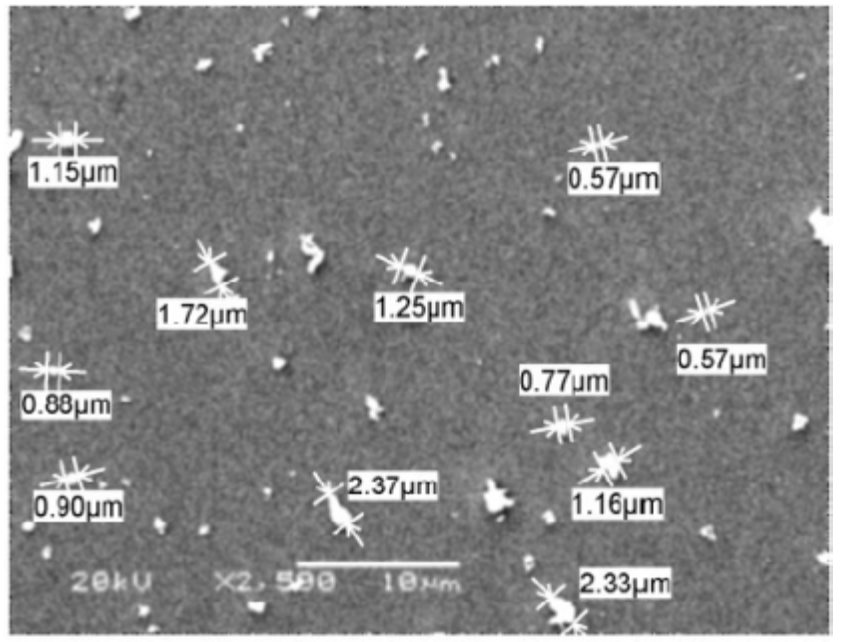

(d)

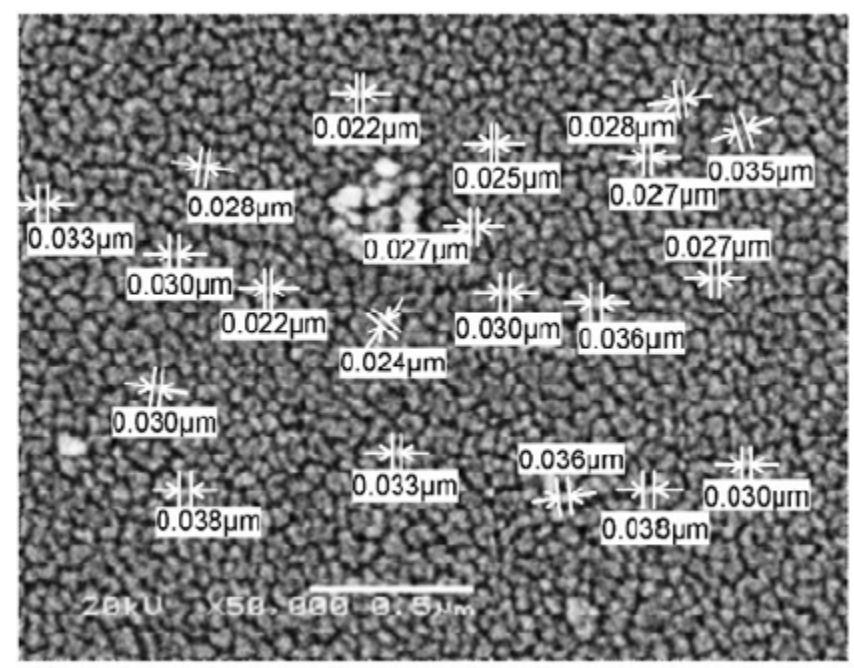

Figure 1a: SEM images of effect of milling period (hr) on $\mathrm{SiO}_{2} \mathrm{NPs}$ size

(Sand weight: $25 \mathrm{~g}$; Water volume: $50 \mathrm{ml}$; Media weight: $113 \mathrm{~g}$; Mill speed: 400rpm; milling period $6 \mathrm{hr}$ )

in Figures 9 and 10. The data of EDS of white and yellow sand before milling are shown in Tables 2, 3, respectively. The EDS measurements of the milled white and yellow sand show that the whole area of silica obtained was around stoichiometric composition (\% At. $\mathrm{Si}=32.90$ and $\mathrm{O}=66.30)$ and $(\%$ At. $\mathrm{Si}=30.27$ and $\mathrm{O}=65.07)$, respectively, as shown in Figures 11 and 12, respectively. The iron appearing in the sample of white sand, Table 4 , analyzed after milling insures that the sample was contaminated by iron from the stainless steel jar or the balls of the ball mill used. Also, the increase in iron content in $\mathrm{SiO}_{2} \mathrm{NPs}$ obtained from milling of yellow sand from $0.15 \%$ to 2.15 , Table 5 , can be attributed to the same reasons.

FTIR: The FTIR spectra of the silica obtained from the milling of white sand and yellow sand Figures 13 and 14, show common bands assigned to various vibrations in the solid, respectively. The analysis of these spectra revealed the weak broad band centered at around $3440.77 \mathrm{~cm}^{-1}$ for $\mathrm{S}_{\mathrm{Si1}}$ and strong broad band centered at around 3435.95 $\mathrm{cm}^{-1}$ for $\mathrm{S}_{\mathrm{Si} 2}$ to correspond to the overlapping of the $\mathrm{O}-\mathrm{H}$ stretching bands of hydrogen-bonded water molecules $(\mathrm{H}-\mathrm{O}-\mathrm{H}$...H) and $\mathrm{SiO}-\mathrm{H}$ stretching of surface silanols hydrogen-bonded to molecular water $\left(\mathrm{SiO}-\mathrm{H}_{\mathrm{N}} . . \mathrm{H}_{2} \mathrm{O}\right)$ [21]. The weak absorption band for $\mathrm{S}_{\mathrm{Sil}}$ and The medium intense absorption band for $\mathrm{S}_{\mathrm{Si} 2}$ corresponding to the adsorbed water molecules deformation vibrations appear at 1615.27 and $1633.59 \mathrm{~cm}^{-1}$, [22], respectively. The medium broad band at $1448.44 \mathrm{~cm}^{-1}$ revealed to symmetric and asymmetric bending of $\mathrm{C}-\mathrm{H}$ bond of $-\mathrm{CH}_{2}-\mathrm{CH}_{2}-$ and very intense broad band at $1161.07 \mathrm{~cm}^{-1}$ assigned to the longitudinal 
Citation: AkI MA, Aly HF, Soliman HMA, Aref ME, EIRahman A, et al. (2013) Preparation and Characterization of Silica Nanoparticles by Wet Mechanical Attrition of White and Yellow Sand. J Nanomed Nanotechnol 4: 183. doi:10.4172/2157-7439.1000183

B) $8 \mathrm{hr}$

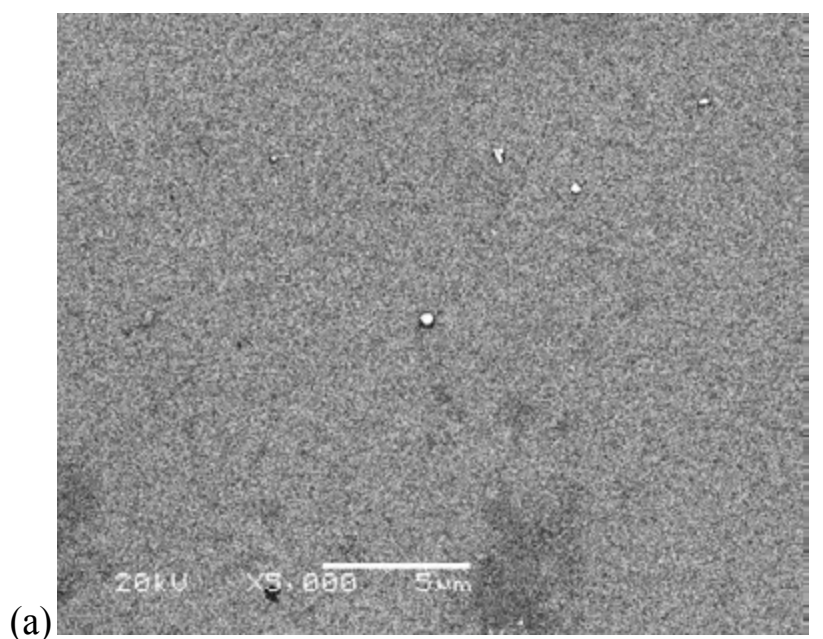

(c)

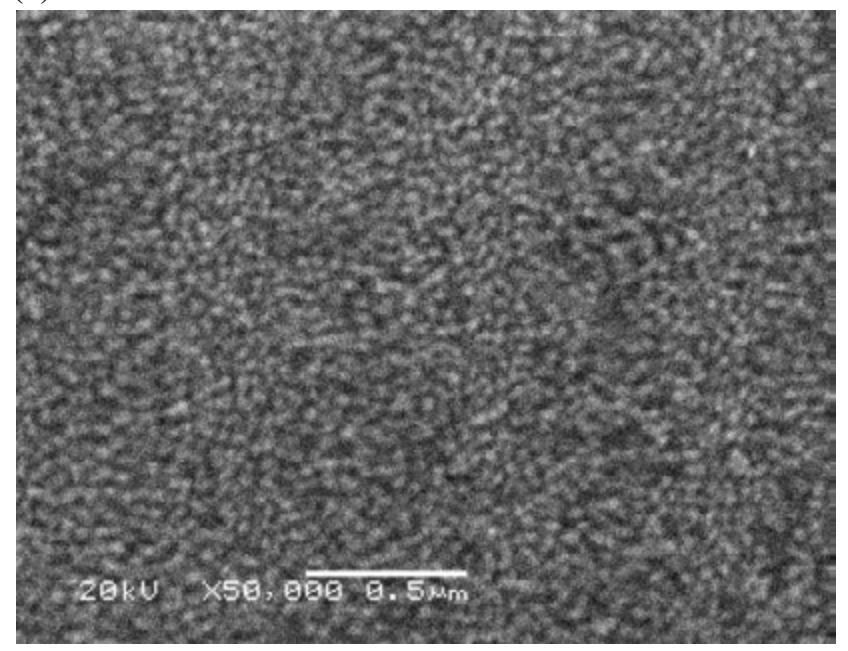

(b)

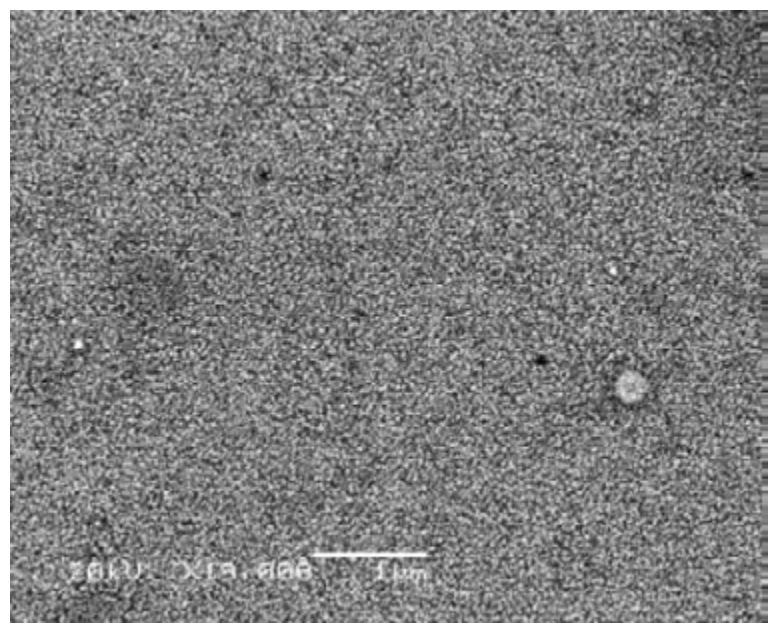

(d)

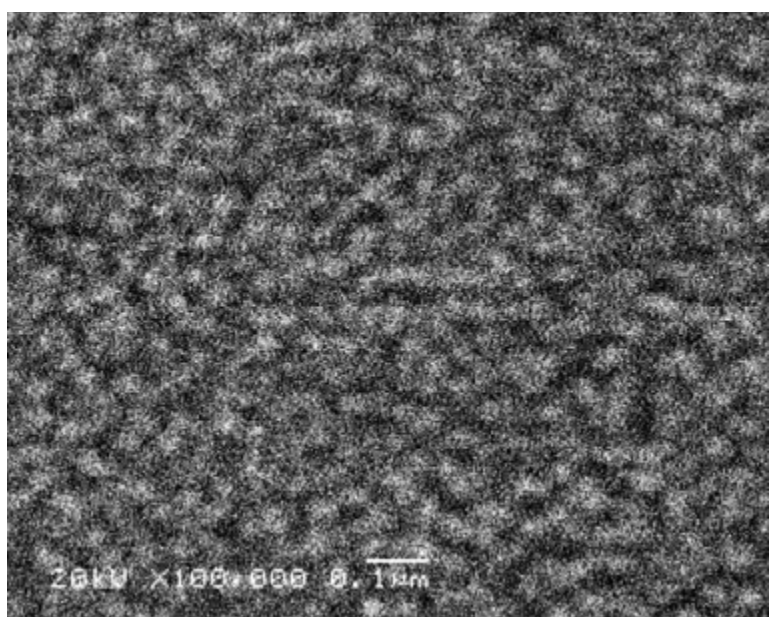

(e)

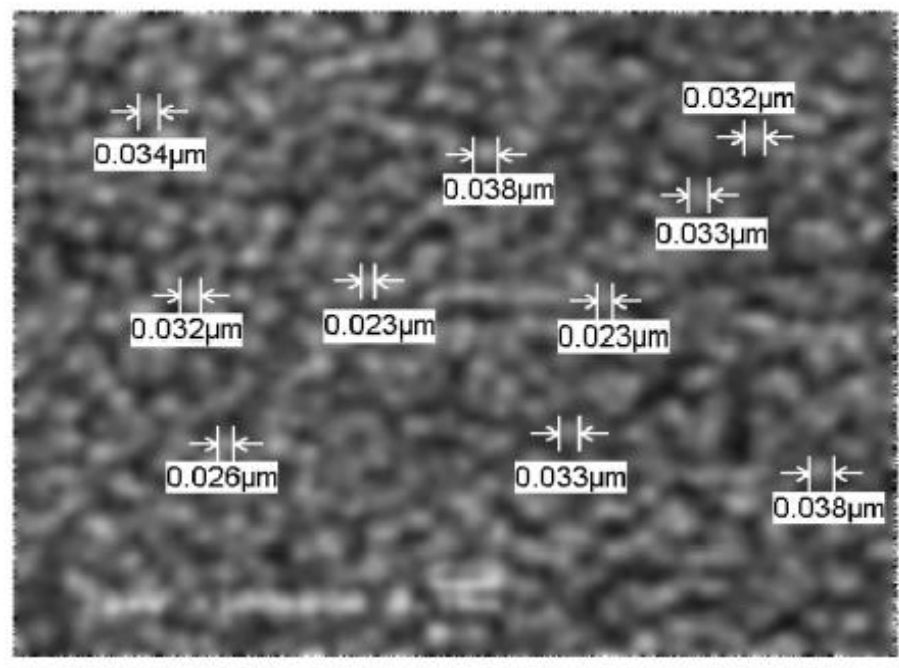

Figure 1b: SEM images of effect of milling period (hr) on the size of $\mathrm{SiO}_{2} \mathrm{NPs}$ (Sand weight: $25 \mathrm{~g}$; Water volume: 50 ml; Media weight: $113 \mathrm{~g}$; Mill speed: 400rpm; milling period $8 \mathrm{hr}$ ) 
Citation: Akl MA, Aly HF, Soliman HMA, Aref ME, EIRahman A, et al. (2013) Preparation and Characterization of Silica Nanoparticles by Wet Mechanical Attrition of White and Yellow Sand. J Nanomed Nanotechnol 4: 183. doi:10.4172/2157-7439.1000183

1. C) $16 \mathrm{hr}$
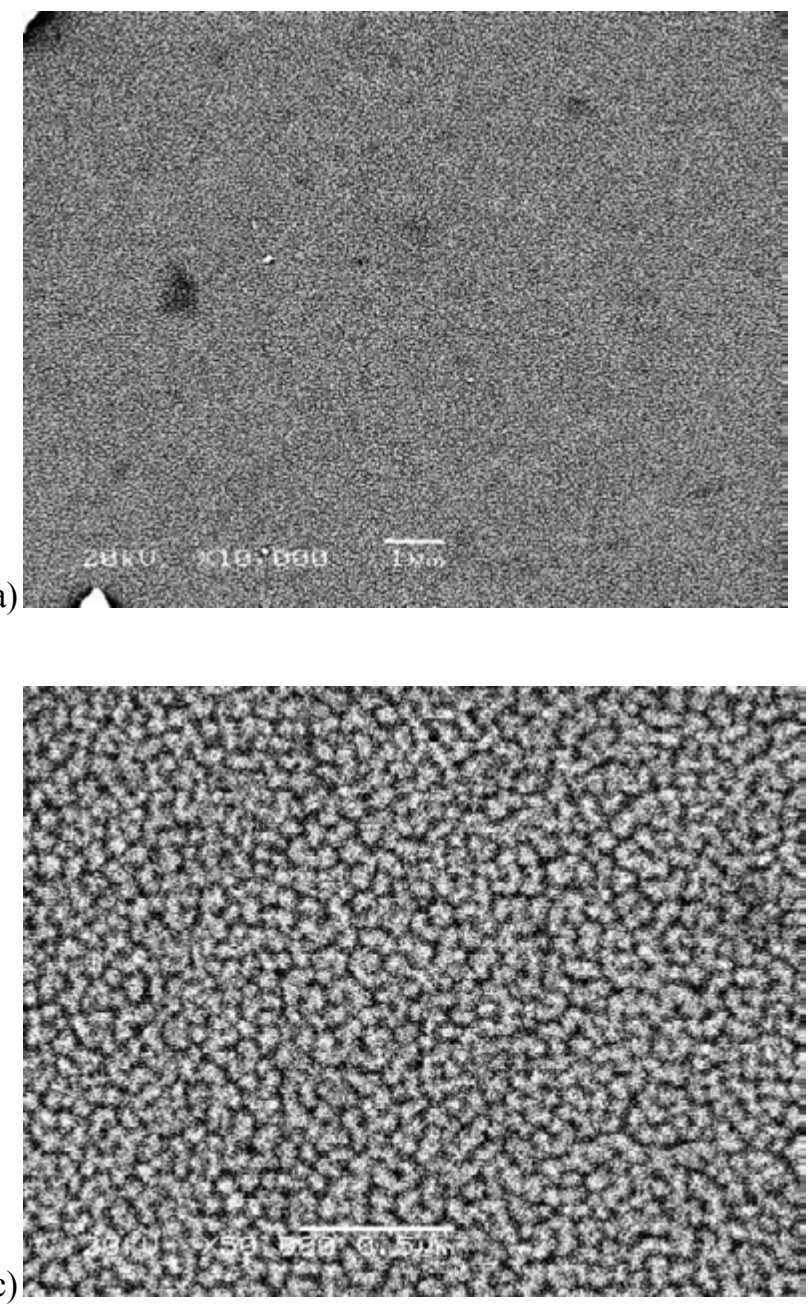

(b)

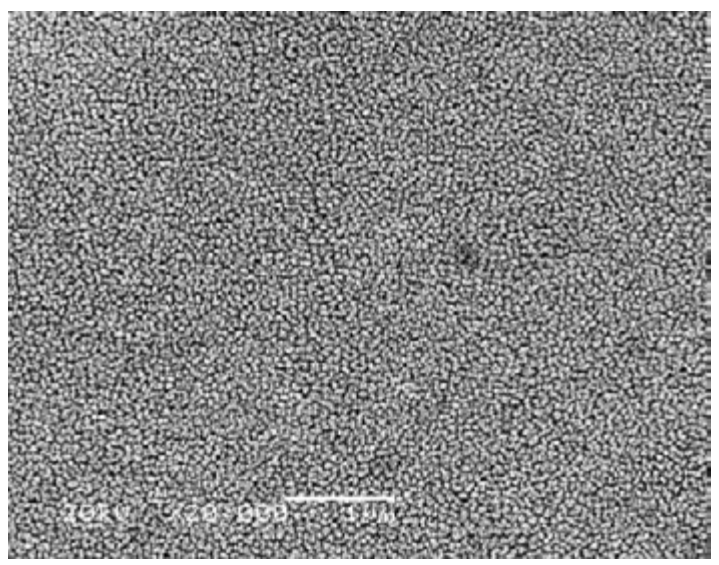

(d)

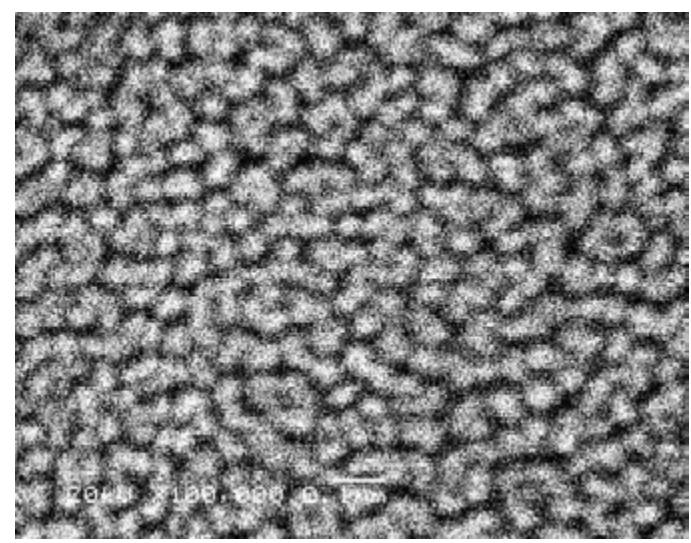

(e)

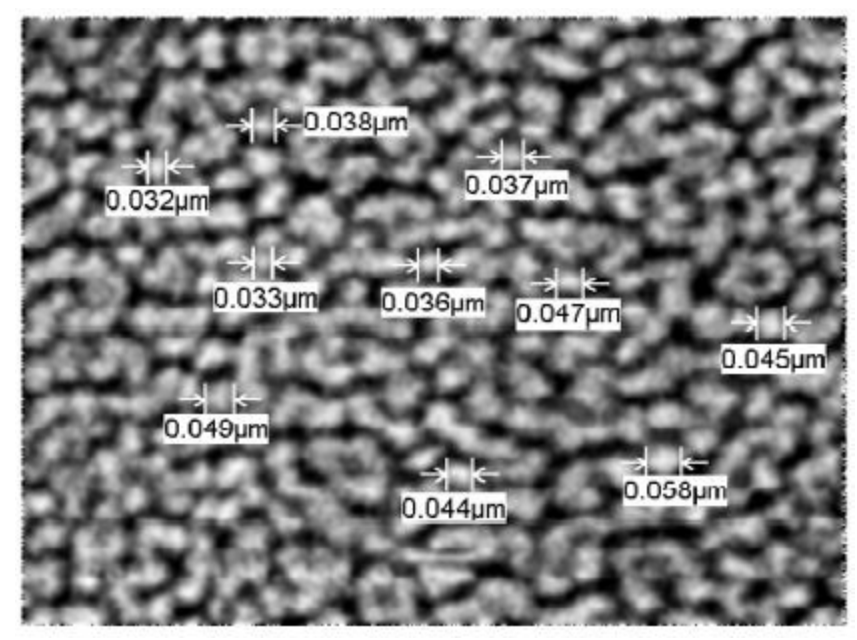

Figure 1c: SEM images of effect of milling period (hr) on $\mathrm{SiO}_{2}$ particle size (Sand weight: $25 \mathrm{~g}$; Water volume: $50 \mathrm{ml}$; Media weight: $113 \mathrm{~g}$; Mill speed: 400 $\mathrm{rpm}$; milling period $6 \mathrm{hr}$ ) 
Citation: AkI MA, Aly HF, Soliman HMA, Aref ME, EIRahman A, et al. (2013) Preparation and Characterization of Silica Nanoparticles by Wet Mechanical Attrition of White and Yellow Sand. J Nanomed Nanotechnol 4: 183. doi:10.4172/2157-7439.1000183

D) $40 \mathrm{hr}$

(a)

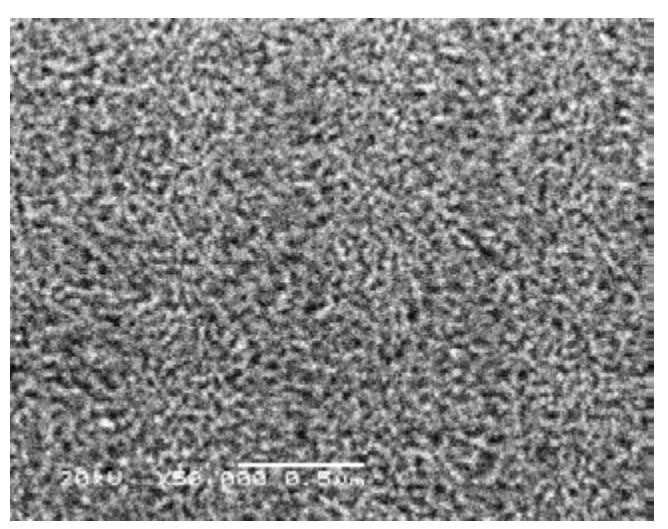

(b)

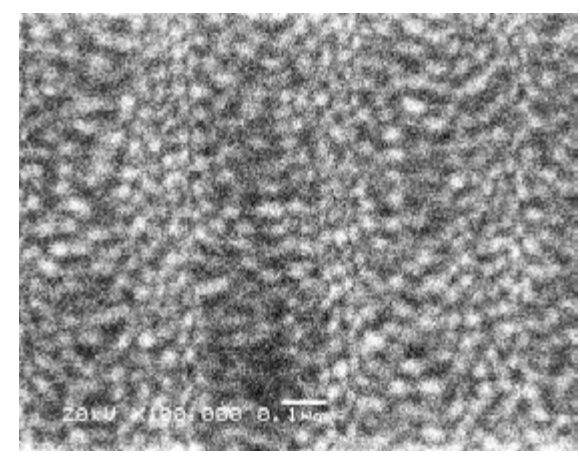

(c)

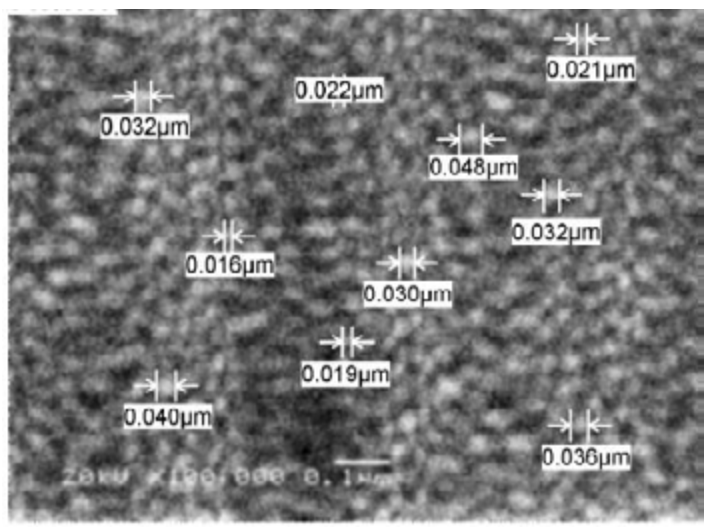

Figure 1d: SEM images of effect of milling period (hr) on $\mathrm{SiO}_{2} \mathrm{NPs}$ size (Sand weight: $25 \mathrm{~g}$; Water volume: $50 \mathrm{ml}$; Media weight: $113 \mathrm{~g}$; Mill speed: $400 \mathrm{rpm}$; milling period $6 \mathrm{hr}$ )

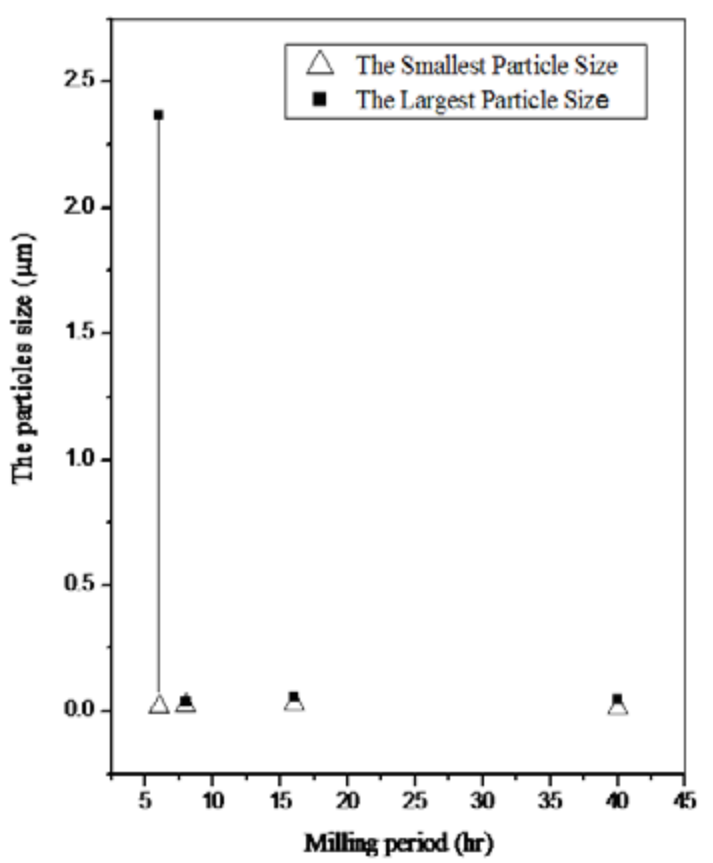

Figure 2: Effect of milling period on $\mathrm{SiO}_{2} \mathrm{NPs}$ (sand wt. $25 \mathrm{~g}$, water volume $50 \mathrm{ml}$, media wt. $113 \mathrm{~g}$, mill speed $400 \mathrm{rpm}$ ) 
Citation: AkI MA, Aly HF, Soliman HMA, Aref ME, EIRahman A, et al. (2013) Preparation and Characterization of Silica Nanoparticles by Wet Mechanical Attrition of White and Yellow Sand. J Nanomed Nanotechnol 4: 183. doi:10.4172/2157-7439.1000183

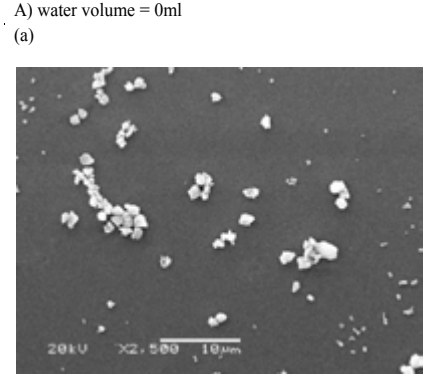

(b)

(c)
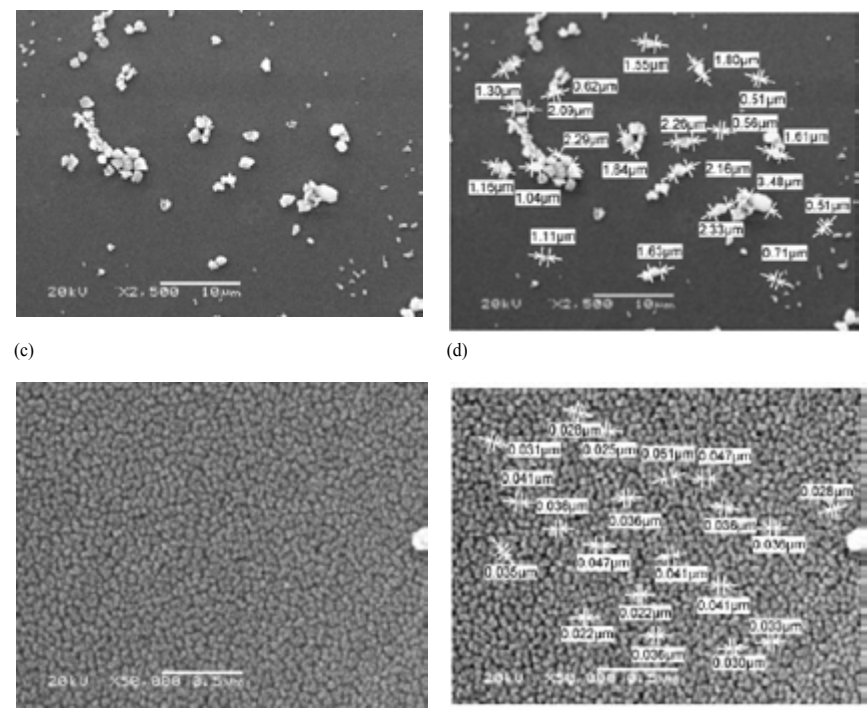

3. B) water volume $=25 \mathrm{ml}$

(a)
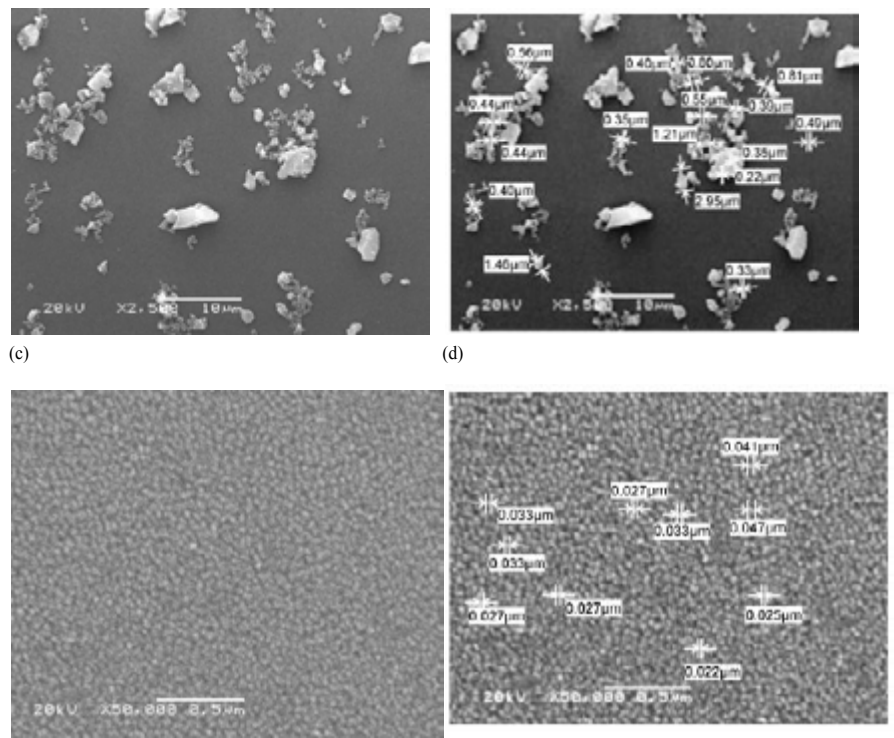

3.C) water volume $=50 \mathrm{ml}$

(a)
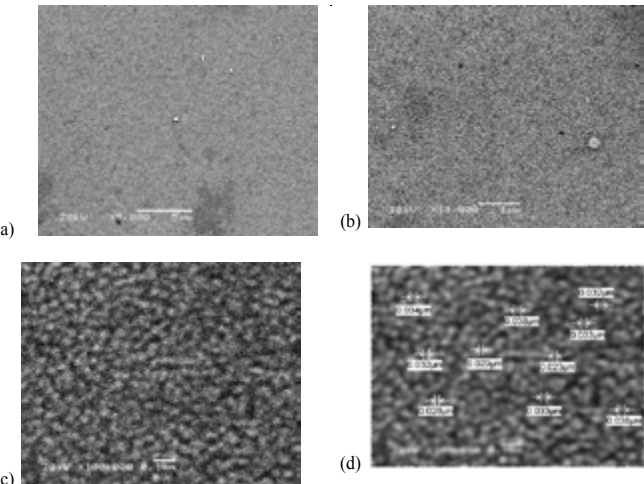

Figure 3: SEM images of effect of water volume $\mathrm{SiO}_{2} \mathrm{NPs}$ (Milling period: $8 \mathrm{hr}$, Sand weight: $25 \mathrm{~g}$, Media weight: $113 \mathrm{~g}$, Mill speed: $400 \mathrm{rpm}$.) A) Water volume $=0 \mathrm{ml}$, B) $25 \mathrm{ml}$ and C) $50 \mathrm{ml}$ 
Citation: AkI MA, Aly HF, Soliman HMA, Aref ME, EIRahman A, et al. (2013) Preparation and Characterization of Silica Nanoparticles by Wet Mechanical Attrition of White and Yellow Sand. J Nanomed Nanotechnol 4: 183. doi:10.4172/2157-7439.1000183
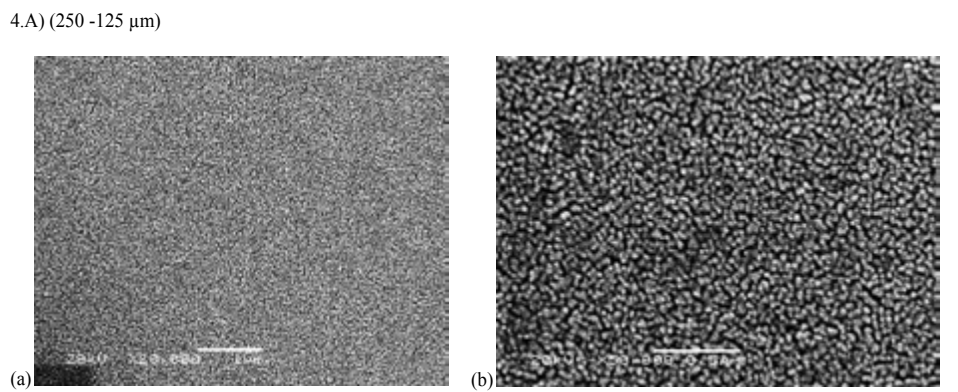

(c)

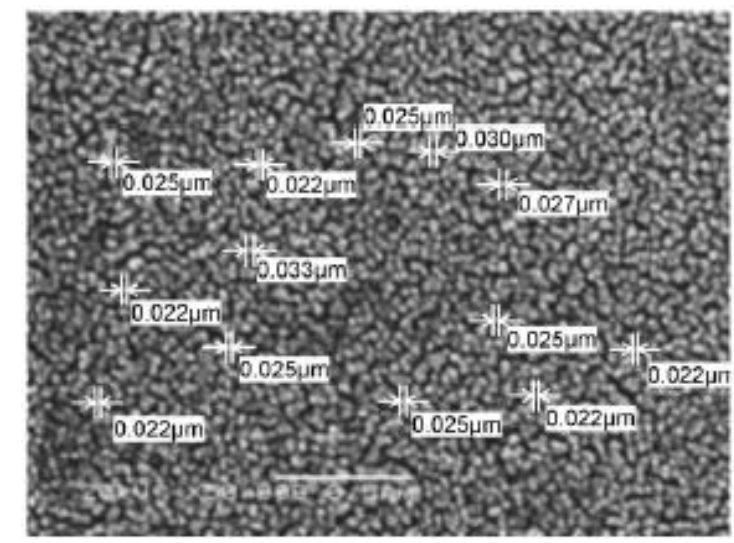

4. B) $(500-250 \mu \mathrm{m})$
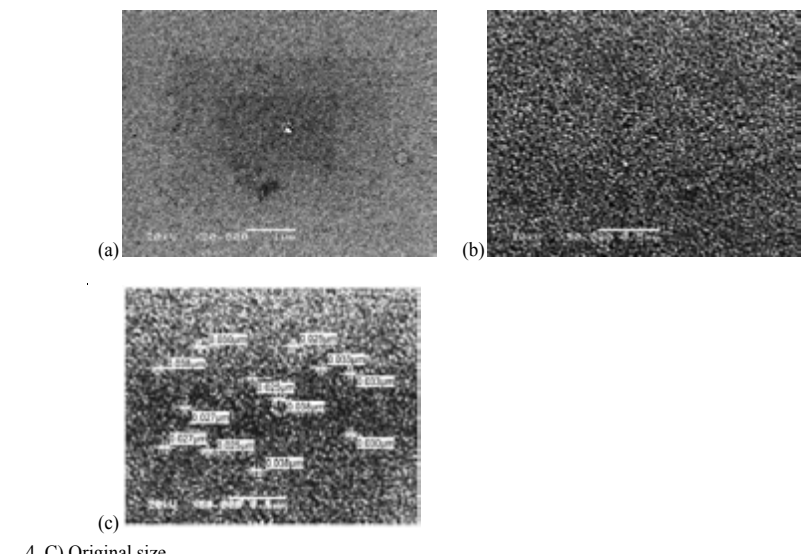

(b)

4. C) Original size

(a)
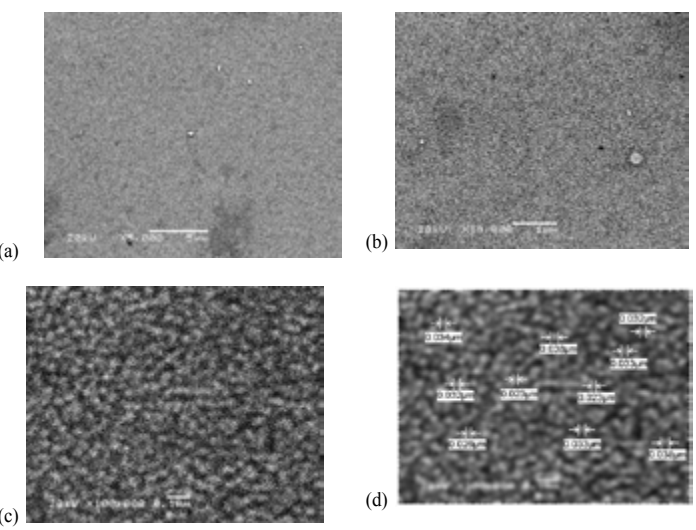

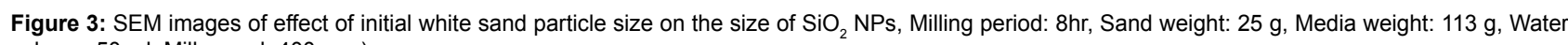
volume: $50 \mathrm{ml}$, Mill speed: $400 \mathrm{rpm})$.

A) $(250-125 \mu \mathrm{m})$, B) $(500-250 \mu \mathrm{m})$ and C) original size 
Citation: AkI MA, Aly HF, Soliman HMA, Aref ME, EIRahman A, et al. (2013) Preparation and Characterization of Silica Nanoparticles by Wet Mechanical Attrition of White and Yellow Sand. J Nanomed Nanotechnol 4: 183. doi:10.4172/2157-7439.1000183

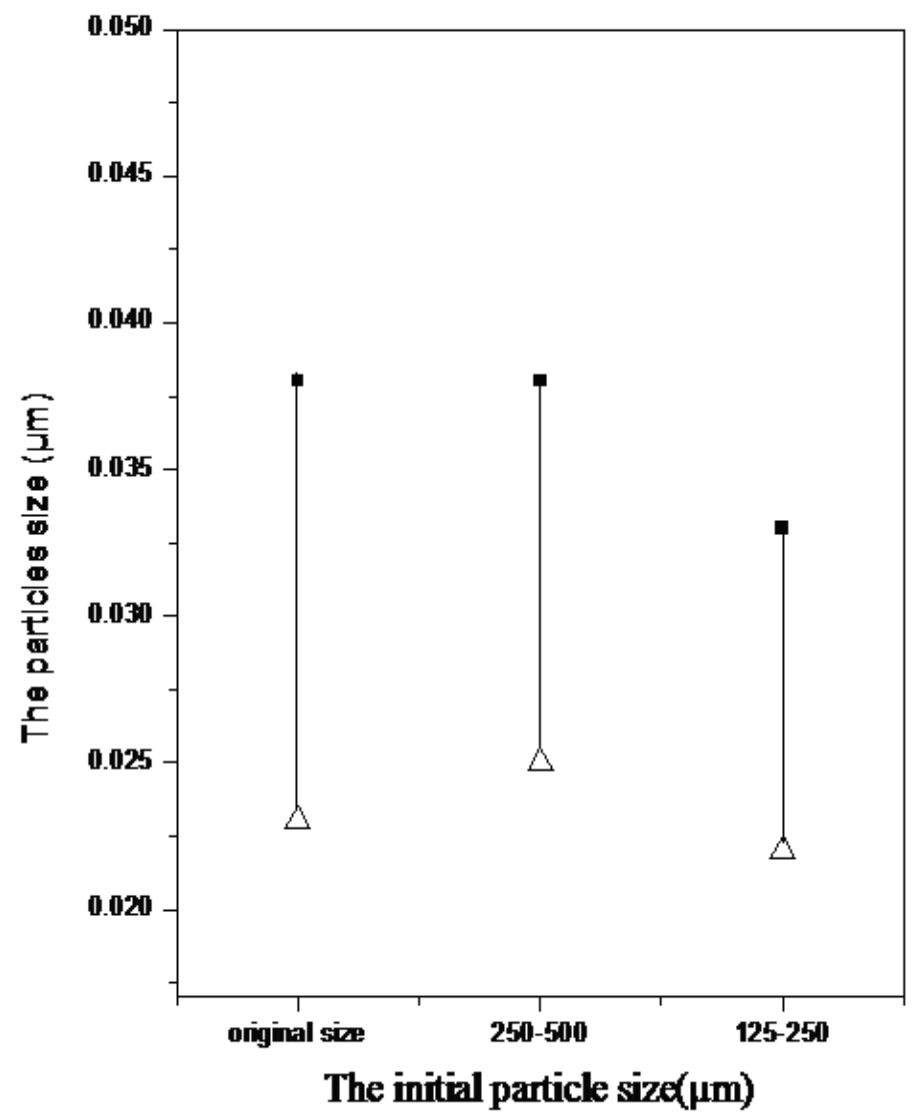

Figure 5: Effect of initial particle size on $\mathrm{SiO}_{2} \mathrm{NPs}$ (milling period $8 \mathrm{hr}$, water volume $50 \mathrm{ml}$, media wt. $113 \mathrm{~g}$, mill speed $400 \mathrm{rpm}$ ).

(a)

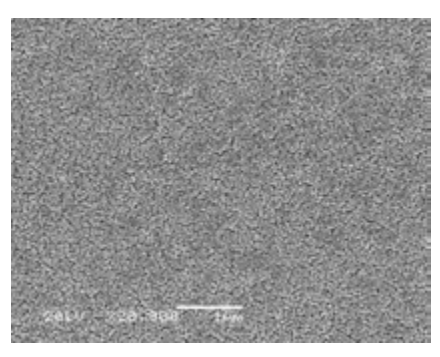

(b)

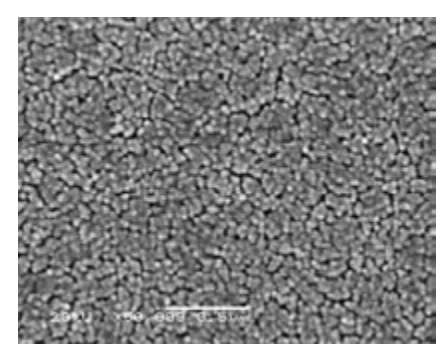

(c)

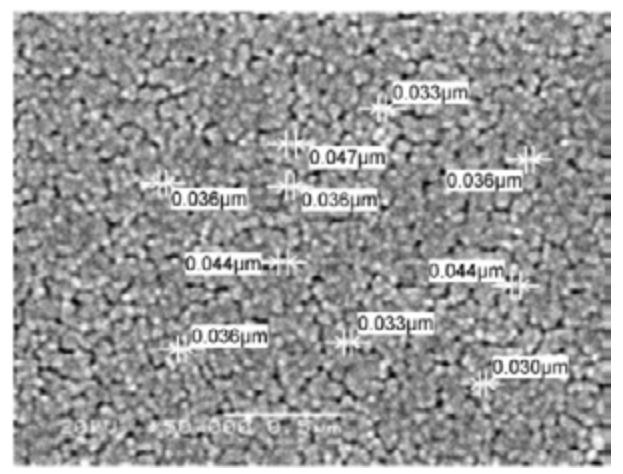

Figure 6: SEM images of the yellow sand particle size obtained at Milling period: $8 \mathrm{hr}$, Sand weight: $25 \mathrm{~g}$, Water volume: $50 \mathrm{ml}$, Media weight: $113 \mathrm{~g}$ and mill speed: $400 \mathrm{rpm}$. 
Citation: AkI MA, Aly HF, Soliman HMA, Aref ME, EIRahman A, et al. (2013) Preparation and Characterization of Silica Nanoparticles by Wet Mechanical Attrition of White and Yellow Sand. J Nanomed Nanotechnol 4: 183. doi:10.4172/2157-7439.1000183
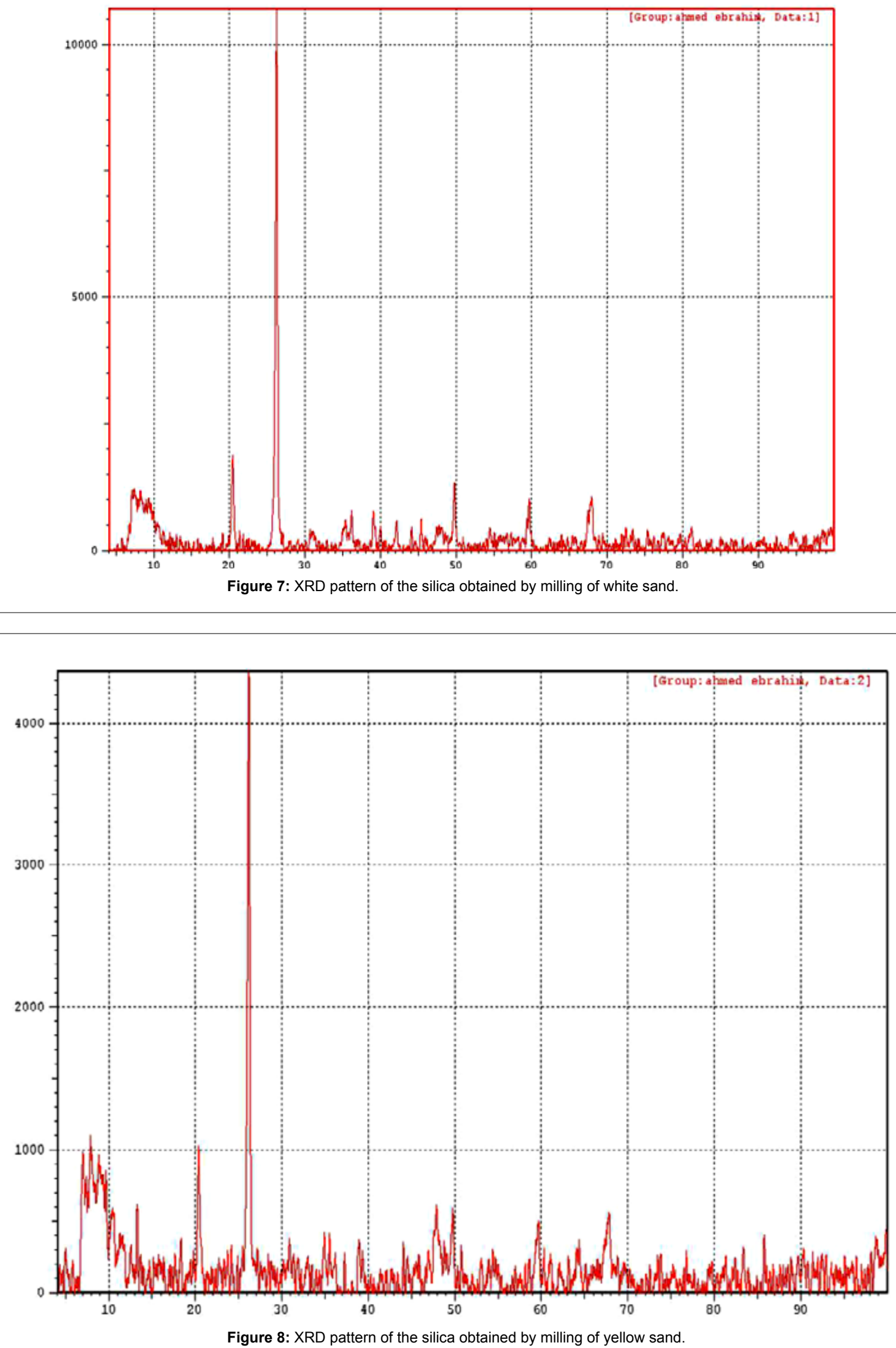
Citation: AkI MA, Aly HF, Soliman HMA, Aref ME, EIRahman A, et al. (2013) Preparation and Characterization of Silica Nanoparticles by Wet Mechanical Attrition of White and Yellow Sand. J Nanomed Nanotechnol 4: 183. doi:10.4172/2157-7439.1000183

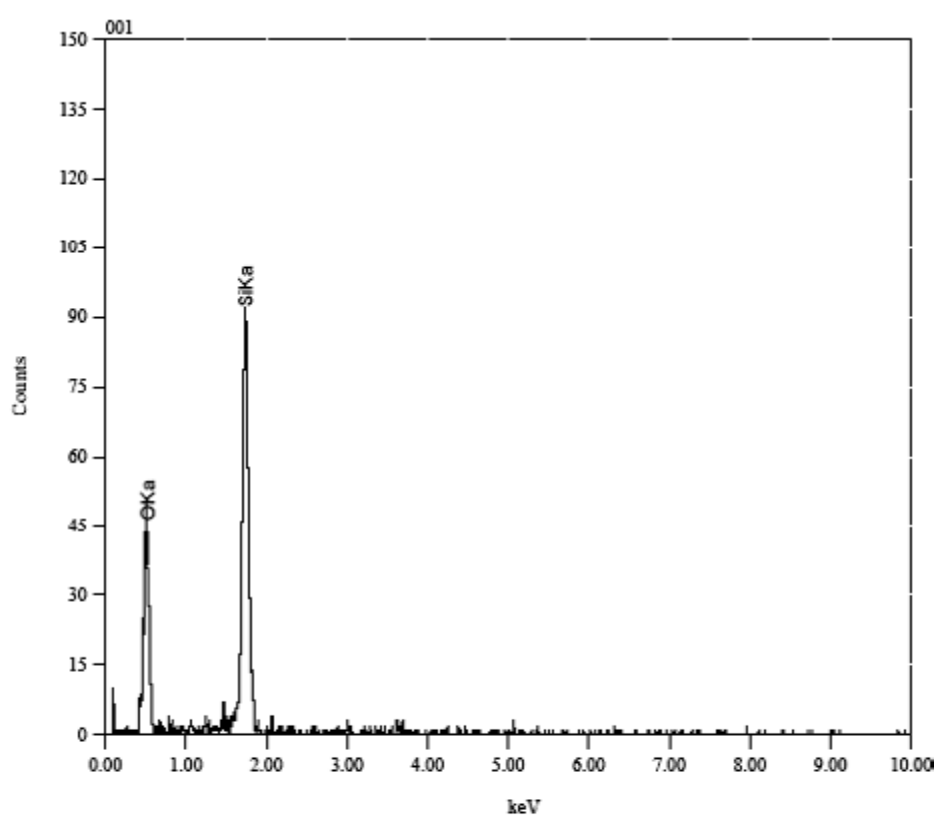

$\begin{array}{lllllll} & \text { Elcmcnt } & (\mathrm{kcV}) & \text { mass\% Error\%At\% } & \text { Compound } & \text { mass\% Ca } \\ \text { O K } & 0.525 & 56.23 & 0.44 & 69.28 & & 58.7225 \\ \text { Si K } & 1.739 & 43.77 & 0.28 & 30.72 & & 41.2775 \\ \text { Total } & 100.00 & 100.00 & & & \end{array}$

Figure 9: The EDS analysis for white sand before the milling.

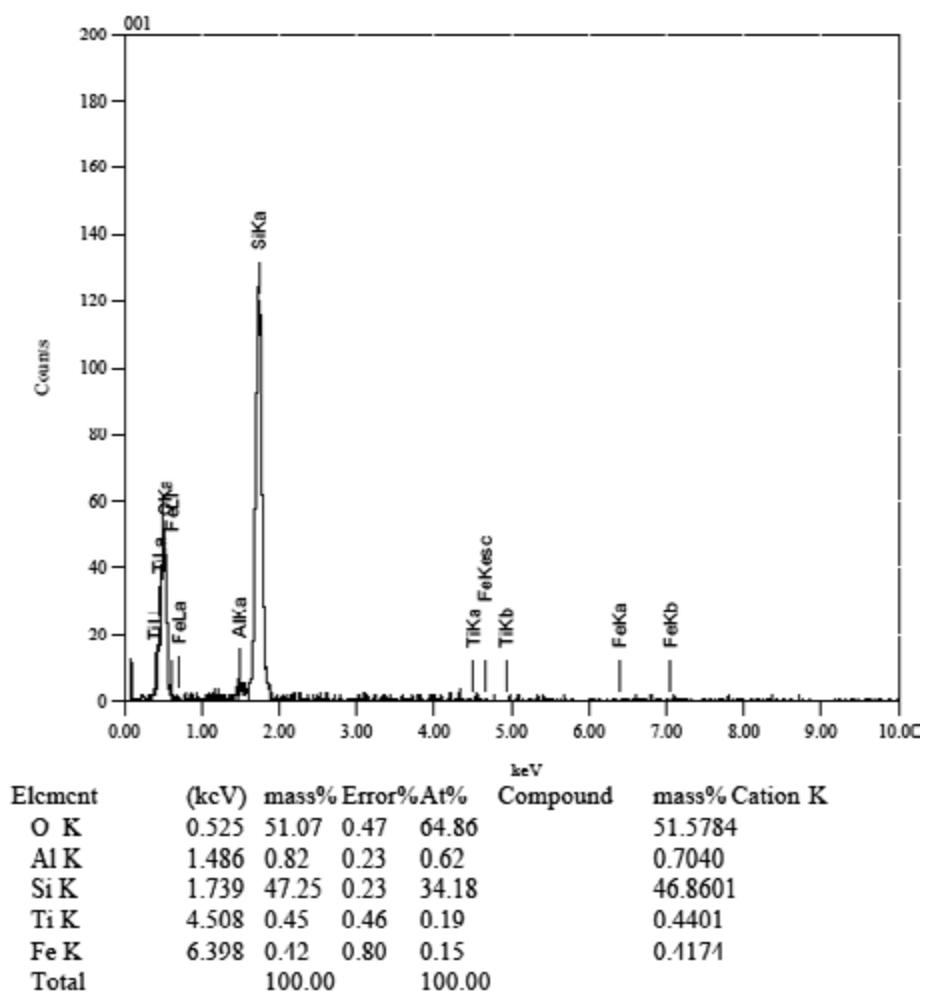

Figure 10: EDS analysis for yellow sand from Borg Al-Arab desert before milling. 
Citation: AkI MA, Aly HF, Soliman HMA, Aref ME, EIRahman A, et al. (2013) Preparation and Characterization of Silica Nanoparticles by Wet Mechanical Attrition of White and Yellow Sand. J Nanomed Nanotechnol 4: 183. doi:10.4172/2157-7439.1000183

Page 12 of 14

\begin{tabular}{|c|c|c|c|c|c|}
\hline Element & KeV & Mass\% & Error\% & $\begin{array}{c}\text { At\% } \\
\text { compound }\end{array}$ & $\begin{array}{c}\text { Mass \% cation } \\
\text { K }\end{array}$ \\
\hline OK & 0.525 & 56.23 & 0.44 & 69.28 & 58.7225 \\
\hline Sik & 1.739 & 43.77 & 0.28 & 30.72 & 41.2775 \\
\hline Total & & 100.00 & & 100.00 & \\
\hline
\end{tabular}

Table 2: Elemental analysis of white sand before milling

\begin{tabular}{|c|c|c|c|c|c|}
\hline Element & KeV & Mass\% & Error\% & At\% compound & Mass \% cation K \\
\hline OK & 0.525 & 4 & 0.47 & 64.86 & 51.5784 \\
\hline AlK & 1.486 & 0.82 & 0.23 & 0.62 & 0.7040 \\
\hline TiK & 4.508 & 0.45 & 0.46 & 0.19 & 0.4401 \\
\hline Sik & 1.739 & 43.77 & 0.28 & 32.90 & 43.7741 \\
\hline FeK & 6.398 & 0.42 & 080 & 0.15 & 0.4174 \\
\hline Total & & 100.00 & & 100.00 & \\
\hline
\end{tabular}

Table 3: Elemental analysis of yellow sand brfore milling.

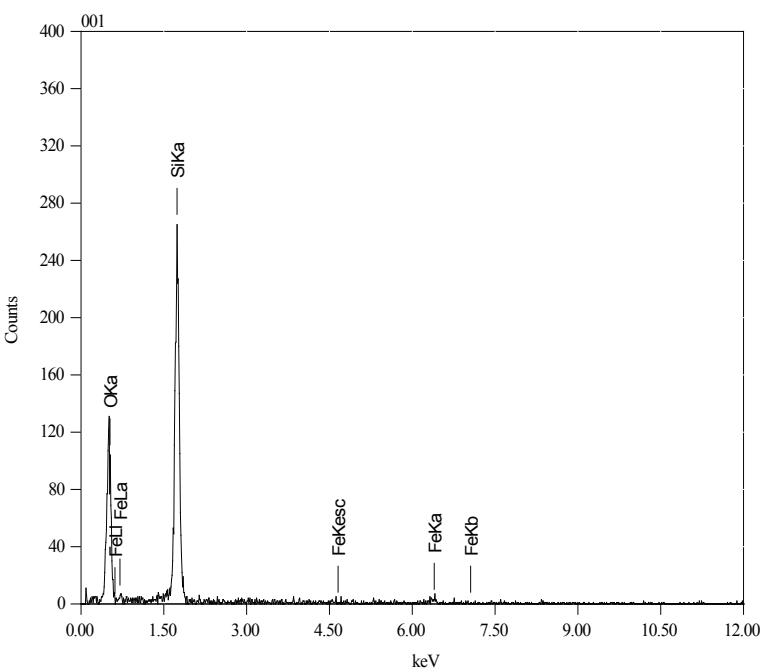

$\begin{array}{lcllll}\text { Element } & (\mathrm{keV}) & \text { mass\% } & \text { Error\% } & \text { At\% Compound mass\% Cation K } \\ \text { O K } & 0.525 & 52.26 & 0.40 & 66.30 & 54.0522 \\ \text { Si K } & 1.739 & 45.53 & 0.25 & 32.90 & 43.7741 \\ \text { Fe K } & 6.398 & 2.21 & 0.88 & 0.80 & 2.1738 \\ \text { Total } & & 100.00 & & 100.00 & \end{array}$

Figure 11: The EDS analysis for $\mathrm{SiO}_{2}$ obtained by milling of white sand.

optical (LO) modes of the Si-O-Si asymmetric stretching vibrations [23] which found in $\mathrm{S}_{\mathrm{Si} 2}$ and absence in $\mathrm{S}_{\mathrm{Si1}}$. The very intense and broad band appearing at $1082.96 \mathrm{~cm}^{-1}$ and 1083.92 assigned to the transversal optical (TO) modes of the Si-O-Si asymmetric stretching vibrations [23] for $\mathrm{S}_{\mathrm{Si1}}$ and $\mathrm{S}_{\mathrm{Si} 2}$ respectively. On the other hand, the symmetric stretching vibrations of Si-O-Si appear at $785.94 \mathrm{~cm}^{-1}$ and its bending mode appears at $459.63 \mathrm{~cm}^{-1}$ and $479.28 \mathrm{~cm}^{-1}$ [24] for $\mathrm{S}_{\mathrm{Si} 1}$ and $\mathrm{S}_{\mathrm{Si} 2}$ respectively. The weak shoulder band at around $698.63 \mathrm{~cm}^{-1}$ and 692.40 $\mathrm{cm}^{-1}$ for $\mathrm{S}_{\mathrm{Si1}}$ and $\mathrm{S}_{\mathrm{Si} 2}$ respectively is assigned to $\mathrm{Si}-\mathrm{O}$ stretching of the $\mathrm{SiO}_{2}$ [25]. This difference in spectra between $\mathrm{S}_{\mathrm{Si1}}$ and $\mathrm{S}_{\mathrm{Si} 2}$ may attributed to the impurities present in yellow sand such as $\mathrm{Al}$ and $\mathrm{Ti}$.

\section{Conclusion}

Mechanical alloying is a simple and useful processing technique that is now being employed in the production of nanocrystals and/or nanoparticles from all material classes. Although a variety of mechanical alloying devices exist, the high-energy ball mill is typically used to produce particles in the nanoscale size range. Particle size reduction is effected over time in the high-energy ball mill, as is a reduction in crystallite grain size, both of which reach minimum values at extended milling times.

Contamination from milling media (e.g., stainless steel vials and balls) is a serious problem that has not yet been thoroughly investigated. Despite these difficulties, MA is more widely used than ever and continues to be applied to the formation of nanoparticles and nanocrystalline structures in an ever-increasing variety of metals, ceramics, and polymers.

In the present work, $\mathrm{SiO}_{2} \mathrm{NPs}$ with particle size range of $23-38 \mathrm{~nm}$ were prepared by milling white and yellow sand in wet conditions using water as wetting agent for $8 \mathrm{hr}$ and $400 \mathrm{rpm}$ mill speed. The $\mathrm{SiO}_{2} \mathrm{NPs}$ obtained are characterized using SEM, X-ray diffraction, EDS and

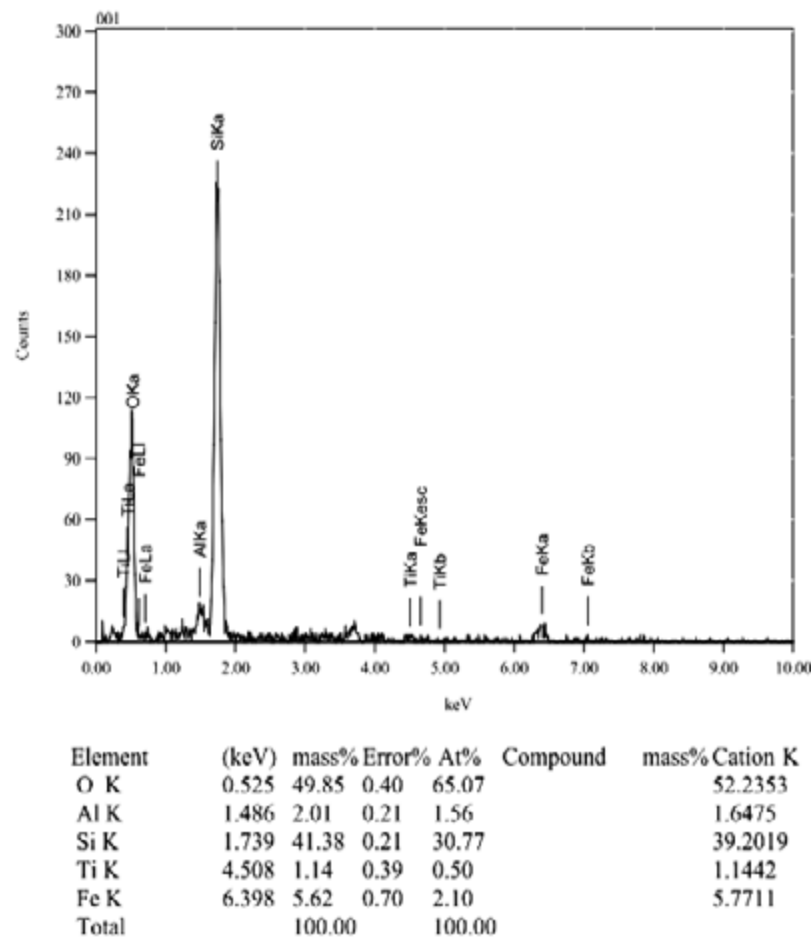

Figure 12: The EDS analysis for $\mathrm{SiO}_{2}$ NPs obtained by milling of yellow sand.

\begin{tabular}{|c|c|c|c|c|c|}
\hline Element & KeV & Mass\% & Error\% & $\begin{array}{c}\text { At\% } \\
\text { compound }\end{array}$ & $\begin{array}{c}\text { Mass \% } \\
\text { cation K }\end{array}$ \\
\hline OK & 0.525 & 52.26 & 0.44 & 66.30 & 54.0522 \\
\hline Sik & 1.739 & 43.77 & 0.28 & 32.90 & 43.7741 \\
\hline FeK & 6.398 & 2.21 & 0.88 & 0.80 & 2.1738 \\
\hline Total & & 100.00 & & 100.00 & \\
\hline
\end{tabular}

Table 4: Elemental analysis of white sand after milling.

\begin{tabular}{|c|c|c|c|c|c|}
\hline Element & KeV & Mass\% & Error\% & At\% compound & Mass \% cation K \\
\hline OK & 0.525 & 49.85 & 0.40 & 65.07 & 52.2353 \\
\hline AlK & 1.486 & 2.01 & 0.21 & 1.56 & 1.6475 \\
\hline TiK & 4.508 & 0.45 & 0.46 & 0.19 & 0.4401 \\
\hline Sik & 1.739 & 41.38 & 0.21 & 30.77 & 39.2019 \\
\hline FeK & 6.398 & 5.62 & 0.70 & 2.10 & 5.7711 \\
\hline Total & & 100.00 & & 100.00 & \\
\hline
\end{tabular}

Table 5: Elemental analysis of yellow sand after milling. 
Citation: AkI MA, Aly HF, Soliman HMA, Aref ME, EIRahman A, et al. (2013) Preparation and Characterization of Silica Nanoparticles by Wet Mechanical Attrition of White and Yellow Sand. J Nanomed Nanotechnol 4: 183. doi:10.4172/2157-7439.1000183

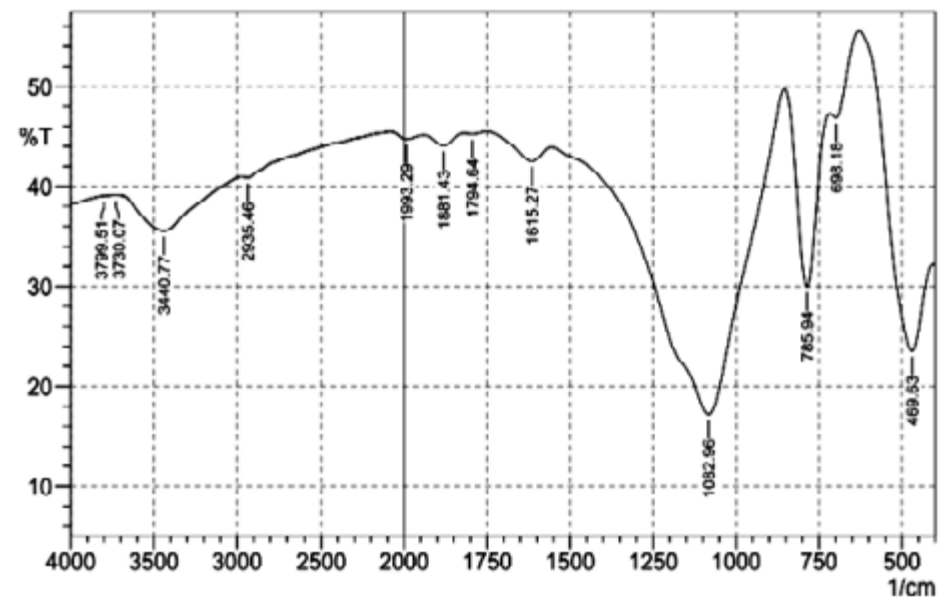

Figure 13: FT-IR spectra of $\mathrm{SiO}_{2} \mathrm{NPs}$ obtained by milling of white.

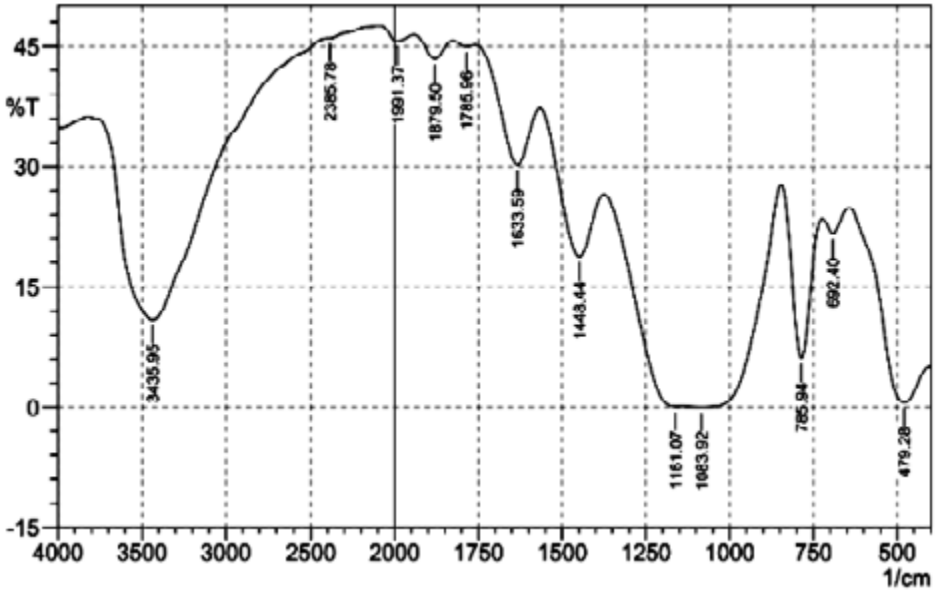

Figure 12: FT-IR spectra of $\mathrm{SiO}_{2}$ NPs obtained by milling of yellow sand .

FTIR. The results showed that the $\mathrm{SiO}_{2}$ NPs have spherical shape and with crystalline structure.

\section{References}

1. Datta MK, Pabi SK, Murty BS (2000) Thermal stability of nanocrystalline Ni silicides synthesized by mechanical alloying. Mater. Sci.Eng. 284: 219-225.

2. Gleiter H (1989) Nanocrystalline materials Prog. Mater. Sci 33: 223-315

3. Murray CB, Sun S, Doyle H, Bitley T (2001) Monodisperse 3d Transition Meta (Co, Ni, Fe) Nanoparticles and Their Assembly into Nanoparticle Superlattices. MRS Bull 26: 981-985.

4. Karch J, Birringer R, Gleiter $\mathrm{H}$ (1987) Ceramics ductile at low temperature Nature 300: 556-558.

5. Siegel RW, Hahn H, Ramasamy S, Zongquan L, Ting L, et al. (1988) Structure and Properties of Nanophase TiO2. J. Phys. Colloq 49: 68-686.

6. Jafarzadeh M, Rahman IA, Sipaut CS (2009) Synthesis of silica nanoparticles by modified sol-gel process: the effect of mixing modes of the reactants and drying techniques. J Sol-Gel Sci Technol 50: 328-336.

7. Zawrah MF, EL-Kheshen AA, Abd-EL-aal H M (2009) Facile And Economic Synthesis of Silica Nanoparticles J Ovonic Resear 5: 129-133.

8. Kota SR, Khalil E, Tsutomu K, Kazumi M, Keisuke M (2005) A novel method for synthesis of silica nanoparticles. J Colloid Interf. Sci 289: 125-131.
9. Sung KP, Ki DK, Hee TK (2002) Colloids \& Surfaces A: Physicochemical and Engineering Aspects 197: 7-17

10. Anna BC, Federica B, Anna MF, Bonaventura F, Cristina L (2006) Powder Technology 167: 45-48.

11. Werner S, Arthur F (1968) Controlled growth of monodisperse silica spheres in the micron size range. J colloid and interface science 26: 62-69.

12. Boguch GH, Tracy MA, Zukoski CF (1988) Preparation of Monodisperse Silica Particles: Control of Size and Mass Fraction. J Non-Crystalline Solids 104 95-106.

13. Abarkan I, Doussineau T, Smaïhi M (2006) Tailored macro/microstructural properties of colloidal silica nanoparticles via microemulsion preparationPolyhedron 25: 1763-1770.

14. Gan LM, Zhang K, Chew C.H (1996) Preparation of silica nanoparticles from sodium orthosilicate in inverse microemulsions. Colloids and Surfaces $A$ Physicochem Engineer Asp I 10: 199206.

15. Zaky RR, Hessien MM, El-Midany AA, Khedr MH, Abdel-Aal EA, et al. (2008) Preparation of silica nanoparticles from semi-burned rice straw ash.Powder Techn 185: 31-35.

16. Zhao M, L Zheng L, Bai X, Li N, Yu L (2009) Fabrication of silica nanoparticles and hollow spheres using ionic liquid microemulsion droplets as templates. Colloids and Surfaces A: Physicochem. Eng. Aspects 346: 229-236.

17. Gao GM, Zou HF, Gan SC, Liu ZJ, An BC, et al. (2009) Preparation and properties of silica nanoparticles from oil shale ash. Powder Techn191: 47-51. 
Citation: AkI MA, Aly HF, Soliman HMA, Aref ME, EIRahman A, et al. (2013) Preparation and Characterization of Silica Nanoparticles by Wet Mechanical Attrition of White and Yellow Sand. J Nanomed Nanotechnol 4: 183. doi:10.4172/2157-7439.1000183

Page 14 of 14

18. Hee DJ (2001) Experimental study of synthesis of silica nanoparticles by a bench-scale diffusion flame reactor. Powder Techn 119: 102-108.

19. Patil A, Chirmade UN, Trivedi V, Lamprou DA, Urquhart A, et al. (2011) Encapsulation of Water Insoluble Drugs in Mesoporous Silica Nanoparticles using Supercritical Carbon Dioxide. J Nanomed \& Nanotechnol 2:111.

20. Morohashi S, Sawahara Y (1973) J. Soc. Mater. Sci Jpn, 22689-22692.

21. Brinker CJ, Scherer GW (1990) Sol-gel Science. The Physics and Chemistry of Sol-gel Processing, Academic, New York, 581
22. Socrates G (2001) Infrared and Raman Characteristic Group Frequencies: Tables and Charts, third ed, Wiley, 245.

23. Duran A, Fernandez-Navarro JM, Casariego P, Joglar A (1986) Optica properties of glass coatings containing Fe and Co. J. Non-Cryst. Solids 82: 69

24. Bertoluzza A, Fagnano C, Morelli MA, Gottardi V, Guglielmi M (1982) Raman and infrared spectra on silica gel evolving toward glass. J Non-Cryst.Solids 48 : 117-128.

25. Gopal NO, Narasimhulu KV, Rao JL (2004) EPR, optical, infrared and Raman spectral studies of Actinolite mineral. Acta Part A 60: 2441-2448. 